\title{
The study of chemical contents, daily values, and microbiology of
}

\section{chicken chili sauce}

\author{
Agus Hadi Prayitno ${ }^{1^{*}}$, Rusna Meswari ${ }^{2}$, and Muhammad Diauddin ${ }^{1}$ \\ ${ }^{1}$ Department of Animal Science Politeknik Negeri Jember, Indonesia \\ ${ }^{2}$ Faculty of Medicine Universiti Kebangsaan Malaysia, Malaysia
}

\begin{abstract}
The chicken chili sauce was made by sautéing cayenne pepper, onion, garlic, salt, sugar, monosodium glutamate, and chicken meat using palm oil. The chili sauce nutrition was improved with the addition of chicken meat for it contains protein common in the community. This study examined the chemical content, daily values, and microbiology of chicken chili sauce. The chemical content parameters analyzed were water, fat, protein, carbohydrate, energy, and vitamin C. The daily values were calculated based on the chemical content of chili sauce with a serving size of $20 \mathrm{~g}$. The microbiological parameters which tested were total plate count, Salmonella, Staphylococcus, and Coliform. The obtained data was analyzed descriptively. The results showed that the chemical content of chicken chili sauce consists of $12.18 \%$ water, $0.88 \%$ ash, $7.88 \%$ protein, $55.91 \%$ fat, $3.14 \%$ carbohydrate, $3.69 \%$ sugar, $627 \mathrm{kcal}$ energy, $41 \mathrm{mg}$ sodium, $5 \mathrm{mg}$ vitamin C, and $7 \mathrm{mek} \mathrm{O}_{2} / \mathrm{kg}$ peroxide numbers. The daily values of chicken chili sauce were calculated based on the average energy sufficiency of 2,150 kcal per person per day with a serving size of $20 \mathrm{~g}$ then by consuming chicken chili sauce per serving can meet the daily needs of fat $16.69 \%$, protein $2.63 \%$, carbohydrate $1.42 \%$, sodium $0.55 \%$, and vitamin C $1.11 \%$. The chicken chili sauce is safe for consumption because the bacterial contamination is low with a total plate count of $1.4 \times 10^{2} \mathrm{CFU} / \mathrm{mg}$, Salmonella, Staphylococcus, and Coliform were negative.
\end{abstract}

\section{Article History}

Received May 12, 2020

Accepted June 30, 2020

\section{Keyword}

Chicken meat,

Chili sauce,

Chili pepper,

Chemical contents,

Daily values.

\section{Introduction}

The chili sauce (sambal) is a food condiment that is very popular among Indonesian people [7]. The chili sauce is a sauce with the main ingredient of chili peppers soaked up with spicy chili pepper content. The chili sauce in the eyes of Indonesian people is a complement to any meal, breakfast, lunch, or dinner that creates a spicy taste in the main dish [8]. The chili sauce has been produced in industrial scale in large numbers $[9,10]$. The chili sauce is also known as saus cabai [11].The sensation of heating and burning on the tongue can be caused by consuming chili sauce which makes it has a specific flavor. The chili sauce can be made from mixed-chili with other complementary ingredients. The chili sauce has its distinctive flavor by mixing different types of chili. Commonly, the chili sauce is made of chili to boost the appetite [12].

Chili is one of the important vegetable commodities in Indonesia. The widely cultivated chili is derived from the species Capsicum annuum L. (large chili and curly chili) and Capsicum frutescens L. (cayenne pepper) [13]. The cayenne pepper (Capsicum frutescens L.) is a plant that has high economic value [14]. The chemical composition of 
cayenne pepper includes $71.2 \%$ water, $4.7 \%$ protein, $19.9 \%$ carbohydrate, $2.4 \%$ fat, $45 \mathrm{mg}$ calcium, $85 \mathrm{mg}$ phosphorus, $70 \mathrm{mg}$ vitamin C, 11,050 SI vitamin A, $2.5 \mathrm{mg}$ iron, and $0.08 \mathrm{mg}$ vitamin B1 [15]. The capsaicin is an active ingredient in chili which has a hot effect on the tongue [16] and can inhibit the oxidation of low-density lipoprotein (LDL) causes of atherosclerosis [17]. For that reason, chili causes spicy sensation when it is added to food.

Indonesia has various types of chili sauce. It happens for the various spices and fruits combined with chili to produce various kinds of chili sauce [8]. Recent research shows that Indonesia has 322 kinds of chili sauce consisting of 257 kinds of chili sauce which were used for cooking and dishes. In general, the main ingredients for making chili sauce are chili, salt, and shrimp paste. The most used ingredients for seasonings are onion, garlic, sugar, and palm oil [18]. The chili sauce is rich of vitamin because chili contains vitamins $A, B, C$, and $E$, as well as minerals such as molybdenum, manganese, folate, potassium, thiamine, and copper. The chili contains seven times more vitamin C compared to oranges [8]. The chili is rich in active compounds flavonoids, capsaicin, minerals, and antioxidant compounds such as vitamin $C$, vitamin $E$, vitamin $K$, phytosterols, $\beta$-carotene, and $\beta$-cryptoxanthin [19].

The chicken chili sauce (sambal suwir ayam) is one of the types of sambal in Indonesia. The chicken chili sauce was made by sautéing cayenne pepper, onion, garlic, salt, monosodium glutamate, sugar, and chicken meat using palm oil. The chili nutrition is enhanced by adding chicken meat because it is the most preferred source of animal protein by most Indonesian people. The chicken meat color is white to slightly yellowish, savory flavor, smooth texture, and tender [20]. The chemical composition of chicken meat includes $72.61 \%$ water, $21.69 \%$ protein, and $4.59 \%$ fat [21]. The meat contains bioactive compounds such as conjugated linoleic acid, carnosine, anserine, L-carnitine, glutathione, taurine, and keratin [22]. The chemical content is one of the qualities of processed food chili sauce used to calculate the daily values. This study aimed to determine the chemical contents, daily values, and microbiology of chicken chili sauce.

\section{Materials and Methods \\ 2.1. Tools}

The tools used in this research were cutting boards, knives, digital scales, blenders, ovens, soxhlet, kjedahl, and furnaces.

\subsection{Ingredients}

The ingredients used in this study were red cayenne pepper, green cayenne pepper, onion, garlic, sugar, salt, monosodium glutamate, broiler chicken fillet, and palm oil.

\subsection{Research Procedures}

The procedures performed in this study include preparation of chili sauce ingredients, chili sauce balancing, chili sauce withering, chili sauce cooking, chili sauce packing, chemical content testing, calculating daily values, and microbiology, and data analysis.

\subsubsection{Preparation materials}

The broiler chicken fillets were washed and then boiled in boiling water for 5 minutes. Then the boiled broiler chicken fillets were fried until the surface was slightly brownish. The fried broiler chicken fillets were then shredded into small pieces. The red cayenne pepper and green cayenne pepper were removed from the stem and washed in running water. The 
garlic and onion skin were removed and after that red cayenne pepper, green cayenne pepper, onion, and garlic were washed thoroughly.

\subsubsection{Weighing materials}

The chicken chili sauce ingredients were weighed based on formulations, namely red and green cayenne pepper (1:1), onion and garlic (5:1), and supplementary ingredients namely salt $3 \%$, MSG $3 \%$, sugar $1.5 \%, 10 \%$ palm oil, and shredded broiler chicken $10 \%$ calculated from the total chili.

\subsubsection{Withering materials}

The red cayenne pepper, green cayenne pepper, onion, garlic were fried using low heat until the ingredients wither then mashed using a blender.

\subsubsection{Cooking chili sauce}

The ingredients that have been mashed were sautéed together with shredded chicken, and other supplementary ingredients such as salt, sugar, and monosodium glutamate with palm oil over low heat for 15-30 minutes or until the sauce is dark. Once cooked, the chili sauce was cooled to room temperature.

\subsubsection{Packaging chili sauce}

The cooked chicken chili sauce was then weighed as much as $140 \mathrm{~g}$ and packaged in a $150 \mathrm{ml}$ food-grade plastic bottle. The top of the bottle was equipped with aluminium foil protection seal to prevent it from leaking and then tightly closed. Next, put the label on the chili sauce packaging and apply plastic seal to coat the outside of the packaging chili sauce.

\subsubsection{Chemical content analysis, daily values, and microbiology}

The chemical contents of chicken chili sauce were analysed. It contains water, protein, carbohydrate, fat, ash, energy, sugar, peroxide number, sodium, and vitamin $C[23,24]$. The daily values of chicken chili sauce were calculated based on the average energy adequacy for the Indonesian population which was $2,150 \mathrm{kcal}$ per person per day with a serving size of $20 \mathrm{~g}[25,26]$. The parameters of microbiology which tested were total plate count, Salmonella, Staphylococcus, and Coliform $[27,28]$.

\subsubsection{Data analysis}

This research has no treatment factor that was provided. The data was obtained through exploration from the analysis of chemical content of chili sauce. The data obtained from the results of chemical analysis were used to calculate the daily values, and microbiological analysis descriptively.

\section{Results and Discussion \\ 3.1. Chemical Contents}

The chemical contents of the chicken chili sauce that tested were water, ash, protein, fat, carbohydrate, sugar, energy, sodium, vitamin C, and peroxide numbers. The results of the chemical contents analysis of chicken chili sauce were presented in Table 1 . It contained water about $12.18 \%$. The water of chicken chili sauce was lower when compared to the water of the sauce which ranges between $28.14-59.6 \%$ [29]. The lower water of chicken chili sauce can be caused by water loss during cooking process [30]. The processed food products 
with low water content values have a longer shelf life. This case because of reduced water activity (Aw) so that it can inhibit bacterial growth [29].

The ash content illustrates the number of unburnt minerals into volatile substances [31] and ash content shows the minerals contained in the chili sauce [32]. The ash content was around $0.88 \%$. This value was lower than the results of previous studies which showed that the ash content ranged from 5.28-6.41\% [32]. This can be caused by the differences in the chili sauce raw material used, so that during the process of making the mineral chili sauce contained in the chili sauce raw material it still exists. The chicken chili sauce protein content of around $7.88 \%$. The levels of chicken chili sauce protein were higher when compared to previous studies which showed that the protein content of chili sauce was around $0.11-0.17 \%$ [29] and protein content in shrimp sauce $1.76-6.00 \%$ [33]. This was due to the presence of chicken meat containing $21.69 \%$ protein added in the processing of chicken chili sauce as a source of protein [21].

\begin{tabular}{|c|c|c|}
\hline No. & Parameter & Total \\
\hline 1. & Water (\%) & 12,18 \\
\hline 2. & Ash (\%) & 0,88 \\
\hline 3. & Protein (\%) & 7,88 \\
\hline 4. & Fat (\%) & 55,91 \\
\hline 5. & Carbohydrate (\%) & 23,14 \\
\hline 6. & Energy (kcal/100 g) & 627 \\
\hline 7. & Sodium (mg/100 g) & 41 \\
\hline 8. & Sugar (\%) & 3,69 \\
\hline 9. & Vitamin C (mg/100 g) & 5 \\
\hline 10. & Peroxide number (mek $\mathrm{O}_{2} / \mathrm{kg}$ ) & 7 \\
\hline
\end{tabular}

The fat of chicken chili sauce was about $55.91 \%$. This value was higher than the fat chili paste which was around 2.09-5.00\% [33]. This was caused by differences in the type of chili sauce and due to the cooking process causing the water content in the sauce to decrease so that the fat content increases. The carbohydrate content of chicken chili sauce was around $23.14 \%$. This value was higher than carbohydrate of shrimp sauce which was around $4.10-9.07 \%$ [33]. This can be influenced by different raw materials used to make chili sauce which chicken chili sauce used red cayenne pepper and green cayenne pepper.

The total energy of shredded chicken sauce is around $627 \mathrm{kcal}$. The energy of shredded chicken chili sauce is higher than the sauce energy which is around 166-283 kcal [29]. This was because chicken chili sauce has a higher than fat content as the largest contributor to the total energy of the chilli sauce. The sodium levels were one of the main quality parameters that contribute to the level of consumer preference and acceptance. The level of sodium chicken chili sauce was about $41 \mathrm{mg} / 100 \mathrm{~g}$. This value was almost similar to a branded chili sauce which contain sodium of $38.2-90.3 \mathrm{mg} / 100 \mathrm{~g}$ [34]. The sodium of the chili sauce was obtained from $(\mathrm{NaCl})$ and monosodium glutamate (MSG) used.

The sugar content was one of the most important quality parameters that contribute to the flavour, palatability, and discoloration of the chicken chili sauce. The sugar of chicken chili sauce was $3.69 \%$. It is lower than the sugar in the sauce which was $25.88-49.77 \%[29]$. This could be influenced by the proportion of sugar used in chicken chili sauce which was less than the sauce. The vitamin C levels of chicken chili sauce were around $5 \mathrm{mg} / 100 \mathrm{~g}$. This value was lower than previous studies which showed the range of vitamin C from 7.04 to 
$9.67 \mathrm{mg} / 100 \mathrm{~g}$ [35]. This could be caused by different materials used in chili sauce. The vitamin $\mathrm{C}$ level is various. The peroxide number of chicken chili sauce was 7 mek $\mathrm{O}_{2} / \mathrm{kg}$. This value showed that the oil used in chicken chili sauce was still in good condition because the limit for a good oil was less than 10 mek $_{2} / \mathrm{kg}$ of material [24].

\subsection{Daily Values}

Daily values (DV) was an average adequacy of daily nutrients for people according to age group, sex, body size, body activity and special physiological conditions to achieve optimal health degrees [25]. The daily values of chicken chili sauce were presented in Table 2.

\begin{tabular}{|c|c|c|}
\hline \multicolumn{3}{|c|}{$\begin{array}{l}\text { Amount per serving } \\
\text { Total energy } 125,4 \mathrm{kcal} \\
\text { Energy from fat } 100,62 \mathrm{kcal}\end{array}$} \\
\hline & & $\%$ DV \\
\hline Total fat & $11,18 \mathrm{~g}$ & $16,69 \%$ \\
\hline Protein & $1,58 \mathrm{~g}$ & $2,63 \%$ \\
\hline Total carbohydrate & $4,63 \mathrm{~g}$ & $1,42 \%$ \\
\hline Sodium & $8,2 \mathrm{mg}$ & $0,55 \%$ \\
\hline Vitamin C & $1 \mathrm{mg}$ & $1,11 \%$ \\
\hline
\end{tabular}

The nutritional facts written on the processed food label must be stated as a percentage of the daily values calculated using the nutrition label reference. The nutrition label reference was calculated based on the average energy sufficiency for the Indonesian population, which was $2,150 \mathrm{kcal}$ per person per day. The nutrient content in processed food must not exceed one hundred percent of the nutritional label reference per day [25].The nutritional facts based on Table 2 can be seen that by consuming $20 \mathrm{~g}$ of chicken chili sauce will be able to meet the daily needs of fat $16.69 \%, 2.63 \%$ protein, $1.42 \%$ carbohydrate, $0.55 \%$ sodium, and vitamin C $1.11 \%$. The chicken chili sauce with a net weight of $140 \mathrm{~g}$ per package. So that the number of servings per container obtained from chicken chili sauce was 7 servings. The food intake of $20 \mathrm{~g}$ of chicken chili sauce was equivalent to fat $11.18 \mathrm{~g}$, protein $1.58 \mathrm{~g}$, total carbohydrate $4.63 \mathrm{~g}$, sodium $8.2 \mathrm{mg}$, and vitamin C $1 \mathrm{mg}$. This value showed that chicken chili sauce was included in good processed food because it required food intake for processed food that was no more than $13 \mathrm{~g}$ of total fat, $4 \mathrm{~g}$ of saturated fat, $60 \mathrm{mg}$ of cholesterol, and $480 \mathrm{mg}$ of sodium [26].

\subsection{Microbiological Contents}

The microbiological contents were one of the important quality parameters of processed food products. It determines the level of eligibility of the food to be consumed. The required food microbiological contents of chicken chili sauce are total plate count, Salmonella, Staphylococcus, and Coliform. 
Table 3. Microbiological contents of chicken chili sauce

\begin{tabular}{clc}
\hline No. & \multicolumn{1}{c}{ Parameter } & Information \\
\hline 1. & TPC (CFU/mg) & $1,4 \times 10^{2}$ \\
2. & Salmonella & $(-)$ negative \\
3. & Staphylococcus & $(-)$ negative \\
4. & Coliform & $(-)$ negative \\
\hline
\end{tabular}

The microbiological contents of chicken chili sauce were presented in Table 3 . The results of chicken chili bacterial analysis showed that for a total plate count of $1.4 \times 10^{2}$ $\mathrm{CFU} / \mathrm{mg}$. This TPC number was lower and still below the maximum limit for TPC chili sauce that was $1 \times 10^{4}$ colonies/g. So that the chicken chili sauce was safe and suitable for consumption $[11,28]$. Other bacterial analysis results on chicken chili sauce such as Salmonella, Staphylococcus, and Coliform results were negative, while for the maximum limit of coliform $(<3 / g)$, mold $\left(5 \times 10^{1}\right.$ colonies/g), and Staphylococcus aureus $\left(1 \times 10^{2}\right.$ colonies/g) so that the chicken chili sauce was proper and safe for consumption [28].

\section{Conclusions}

The results show that the chemical contents of chicken chili sauce consisted of $12.18 \%$ water, $0.88 \%$ ash, $7.88 \%$ protein, $55.91 \%$ fat, 3.14\% carbohydrate, 3.69\% sugar, $627 \mathrm{kcal}$ energy, $41 \mathrm{mg}$ sodium, $5 \mathrm{mg}$ vitamin $\mathrm{C}$, and 7 mek $\mathrm{O}_{2} / \mathrm{kg}$ peroxide numbers. The daily values of chicken chili sauce were calculated based on the average energy sufficiency of 2,150 kcal per person per day with a serving size of $20 \mathrm{~g}$ then by consuming chicken chili sauce per serving can meet the daily needs of fat $16.69 \%$, protein $2.63 \%$, carbohydrate $1.42 \%$, sodium $0.55 \%$, and vitamin C $1.11 \%$. The chicken chili sauce is safe for consumption because the bacterial contamination is still low with a total plate count of $1.4 \times 10^{2} \mathrm{CFU} / \mathrm{mg}$, Salmonella, Staphylococcus, and Coliform were negative.

\section{References}

1. Kuswandi B, Jayus, Restyana A, Abdullah A, Heng LY, Ahmad M. A novel colorimetric food package label for fish spoilage based on polyaniline film. Food Control. 2012;25(1):18-189.

2. Kuswandi B, Nurfawaidi A. On-package dual sensors label based on $\mathrm{pH}$ indicators for real-time monitoring of beef freshness. Food Control. 2017;82(July):e123-e123.

3. Kuswandi B, Wicaksono Y, Ahmad M. Smart packaging : sensors for monitoring of food quality and safety. Sens Instrumen Food Qual. 2011;5(137):137-46.

4. Vanderroost $M$, Ragaert $P$, Devlieghere F, De Meulenaer $B$. Intelligent food packaging: The next generation. Vol. 39, Trends in Food Science and Technology. 2014.

5. Puligundla P, Jung J, Ko S. Carbon dioxide sensors for intelligent food packaging applications. Food Control. 2012;25(1):328-33.

6. Kuswandi B, Jayus, Larasati TS, Abdullah A, Heng LY. Real-Time Monitoring of Shrimp Spoilage Using On-Package Sticker Sensor Based on Natural Dye of Curcumin. Food Anal Methods. 2012;5(4):881-9.

7. Dharma FUPP. Proses Produksi Sambal "Indofood" di PT Indofood CBP Sukes Makmur Tbk Divisi Food Seasoning. Universitas Katolik Soegijapranata; 2017.

8. Indrajaya YC. Perancangan desain kemasan sambal pecel "Bumbu Ndeso" Blitar. J DKV Adiwarna. 2016;1(8):7-13. 
9. Iqbal SZ, Asi MR, Mehmood Z, Mumtaz A, Malik N. Survey of aflatoxins and Ochratoxin $A$ in retail market chilies and chili sauce samples. Food Control. 2017;81:218-23.

10. Low KH, Zain SM, Abas MR, Khan RA. Characterization of commercial chili sauce varieties according to their chemical and physical properties using chemometric methods. Sens Instrum Food Qual Saf. 2009;3(4):203-10.

11. SNI. Saus Cabe. Jakarta: Badan Standardisasi Nasional; 2006.

12. Kim SH, Chung KR, Yang HJ, Kwon DY. Sunchang gochujang (Korean red chili paste): the unfolding of authenticity. J Ethn Foods. 2016;3(3):201-8.

13. SNI. Cabai. Jakarta: Badan Standardisasi Nasional; 2016.

14. Sila S, Sopialena. Efektivitas beberapa fungisida terhadap perkembangan penyakit dan produksi tanaman cabai (Capsicum frutescens). J Agrifor. 2016;15(1):117-30.

15. Rukmana HR. Usaha Tani Cabai Rawit. Yogyakarta: Kanisius; 2002.

16. Sumpena U. Penetapan kadar capsaicin berbagai jenis cabe (Capsicum sp) di Indonesia. Mediagro. 2013;9(2):9-16.

17. Utami R. Sambal, makanan khas Indonesia yang berpotensi mencegah ateroskerosis dan kanker, serta kajian titik kritis kehalalannya. J Agroindustri Halal. 2015;1(1):1-12.

18. Grehenson G. Peneliti UGM Kumpulkan Ragam Sambal dari Seluruh Indonesia [Internet]. 2018 [cited 2020 May 1]. Available from: https://ugm.ac.id/id/berita/16174-peneliti-ugm-kumpulkan-ragam-sambal-dariseluruh-indonesia

19. Alex S. Usaha Tani Cabai Kiat Jitu Bertanam Cabai di Segala Musim. Yogyakarta: Pustaka Baru Press; 2011.

20. Prayitno $A H$, Suryanto $E$, Zuprizal. Kualitas fisik dan sensoris daging ayam broiler yang diberi pakan dengan penambahan ampas virgin coconut oil (VCO) . Bul Peternak. 2010;34(1):55-63.

21. Prastini Al, Widjanarko SB. Pembuatan sosis ayam menggunakan gel porang (Amorphophallus mueleri Blume) sebagai bahan pengikat terhadap karakteristik sosis. J Pangan dan Agroindustri. 2015;3(4):1503-11.

22. Arihara K. Strategies for designing novel functional meat products. Meat Sci. 2006;74(1):219-29.

23. AOAC. Official Methods of Analysis of the Association of Analytical Chemists. 21th ed. Washington DC: Association of Official Analytical Chemist; 2019.

24. SNI. Minyak Goreng. Jakarta: Badan Standardisasi Nasional; 2013.

25. BPOM. Peraturan Kepala Badan Pengawas Obat dan Makanan Republik Indonesia Nomor 9 Tahun 2016 tentang Acuan Label Gizi. Jakarta: Badan Pengawasan Obat dan Makanan; 2016.

26. BPOM. Peraturan Kepala Badan Pengawas Obat dan Makanan Republik Indonesia Nomor HK. 03.1.23.11.11.09909 Tahun 2011 tentang Pengawasan Klaim dalam Label dan Iklan Pangan Olahan. Jakarta; 2011.

27. SNI. Metode Pengujian Cemaran Mikroba dalam Daging, Telur dan Susu, serta Hasil Olahannya. Jakarta: Badan Standardisasi Nasional; 2008.

28. SNI. Batas Maksimum Cemaran Mikroba dalam Pangan. Jakarta: Badan Standardisasi Nasional; 2009.

29. Anandsynal, Mumtaz B, Motalab M, Jahan S, Hoque MM, Saha BK. Nutritional and microbiological evaluation on sauces and ketchups available in Bangladesh. Int Food 
Res J. 2018;25(1):357-65.

30. Ali NA, Khalid NI, Aziz NA, Shamsudin R, Taip FS. Investigation of fouling deposit formation during pasteurization of chili sauce by using lab-scale concentric tubepasteurizer. J Eng Sci Technol. 2014;9(3):334-46.

31. Fauzi AA, Muhsin Z, Sukainah A. Pengaruh variasi larutan perendaman sukun terhadap fisiko kimia tepung sukun. J Pendidik Teknol Pertan. 2016;2:79-86.

32. Indrawati S, Lahming, Sukainah A. Analisis sifat fisiko kimia saus cabai fortifikasi labu siam dan labu kuning. J Pendidik Teknol Pertania. 2018;4:S113-23.

33. Suhartini W, Yang F, Xia W. Physiochemical properties, volatile compounds and sensory evaluation of chili sauce shrimp paste from different regions in Indonesia. Food Nutr Sci. 2019;10(3):333-48.

34. Purawisastra S, Yuniati H. Kandungan natrium beberapa jenis sambal kemasan serta uji tingkat penerimaannya. Penelit Gizi dan Makanan. 2010;33(2):173-9.

35. Supit JW, Langi TM, Ludong MM. Analisis sifat fisikokimia dan organoleptik sambal "Cahero." Cocos. 2005;6(7). 